\title{
Development of site class and site coefficient maps of Semarang, Indonesia using field shear wave velocity data
}

\author{
Windu Partono, ${ }^{1,}$, Masyhur Irsyam ${ }^{2}$, and Sri Prabandiyani Retno Wardani ${ }^{1}$ \\ ${ }^{1}$ Civil Engineering Department, Diponegoro University, 50275 Semarang, Indonesia \\ ${ }^{2}$ Civil Engineering Department, Bandung Institute of Technology, 40132 Bandung, Indonesia
}

\begin{abstract}
The new Indonesian National Code for seismic resistance design (SNI-03-1726-2012) issued recently utilizes seismic response spectra for the whole area of the country. Site class and site coefficient are two parameters needed for designing response spectra. Site class can be estimated using average standard penetration test (N-SPT), average shear wave velocity (Vs) and average un-drained shear strength $(\mathrm{Su})$ of top 30 meter soil deposit. Site coefficients can be predicted using probabilistic seismic hazard analysis (PSHA) by implementing total probability theorem. To perform PSHA, Vs30 is a parameter needed for calculating ground motion at bedrock elevation. This paper presents the results of PSHA and site class analysis using Vs30 values estimated based on N-SPT results collected from 265 boring locations in Semarang. Seismic data in a radius of $500 \mathrm{~km}$ from Semarang were collected for PSHA. Site class and site coefficient maps are then developed for the whole study area.
\end{abstract}

\section{Introduction}

Indonesia has implemented the new seismic design code for building and non-building structure SNI-03-17262012. The code contains maps of Maximum Considered Earthquake Geometric Mean Peak Ground Acceleration $\left(\mathrm{MCE}_{\mathrm{G}}\right)$ and Risk-Targeted Maximum Considered Earthquake $\left(\mathrm{MCE}_{\mathrm{R}}\right)$. The $\mathrm{MCE}_{\mathrm{R}}$ maps were developed by conducting $1 \%$ probability of collapse in 50 years at short-period ( 0.2 second) spectral response acceleration, $\mathrm{S}_{\mathrm{S}}$, and long period (1 second) spectral response acceleration, $\mathrm{S}_{1}$, at bedrock elevation. Site class and site coefficient are two parameters needed for designing response spectra at ground surface. Based on [1] site class can be estimated using average standard penetration test (N-SPT), average shear wave velocity $(\mathrm{Vs})$ and average un-drained shear strength $(\mathrm{Su})$ of top 30 meter soil deposit. An average shear wave velocity in the upper 30 meter soil deposit is referred to as Vs30. Site coefficients can be predicted using PSHA by implementing total probability theorem [2]. This paper presents the results of site class analysis and PSHA using real Vs30 values. The shear wave velocity (Vs) for each soil layer for Vs30 calculations is estimated using N-SPT values. The Vs values were predicted using three empirical equations proposed by [3, 4 and 5]. The objective of this study is to get complete information of Vs30, site class and site coefficient distributions for the whole area of Semarang city for developing site class and site coefficient maps. This study is part of a comprehensive seismic microzonation research of the study area. Seismic microzonation study of Semarang is still on-going as part of seismic mitigation study following the work conducted by the Team for Revision of Seismic Hazard Maps of Indonesia 2010 (TRSHMI2010).

Semarang is the capital city of Central Java Province, Indonesia, and located at the center of the Northern part of Central Java Province. The city has an area of about 374 square kilometers and spans for $22 \mathrm{~km}$ long and 22 $\mathrm{km}$ wide and elongated in North-South and East-West directions. The study area can be separated into two different land-slopes, coastal plain area in the northern part with maximum slope of 5\% and hilly area in the center and southern parts with maximum slope of $33 \%$.

Seismic sources that are significantly influence Semarang are the Java subduction zone and shallow crustal faults $[6,7]$. Three big earthquakes due to subduction zone were reported by [6] including 7.9 Ms (1903), 7.2 Ms (1937) and 7.9 Ms (1977). Asrurifak [2] stated that for the last 300 years no earthquakes occurs with magnitude of more than $8.0 \mathrm{Mw}$. Tectonic condition for Semarang is quite similar to that of Yogyakarta, there is an active fault near both cities. The latest 2006 Yogyakarta earthquake with $6.3 \mathrm{Mw}$ was a destructive earthquake that caused thousands of casualties in Yogyakarta Province [8]. Salahuddin [7] stated that the 2006 Yogyakarta earthquake was caused by Yogya Fault. Learning from Yogyakarta earthquake, Semarang with Lasem Fault required a comprehensive seismic microzonation study for hazard mitigation and disaster preparedness.

Development of site class and site coefficients maps of Semarang was performed using five following procedures: 1) collecting and processing recorded earthquake data for entire Indonesian region from 1900 
until 2013, 2) modeling seismic source zones, 3) determining seismic parameters which include $a-b$ values, maximum magnitudes, and slip-rates, 4) selecting appropriate attenuation functions and 5) conducting the PSHA.

\section{Experiment details}

\subsection{Seismic sources and seismic models}

According to $[2,9]$ the study area is significantly influenced by seismic sources which can be classified into subduction zone, transform zone and diffuse seismicity zone. Following the work conducted by TRSHMI-2010 for developing national seismic hazard maps, seismic sources were divided into subduction, shallow crustal fault, and background sources. The subduction zone at South of Java, the Java segment of the Sunda arc, extends from Sunda Strait on the west to Bali Basin on the East. Old oceanic crust is relatively converging in a direction essentially normal to the arc at the rate of about $60 \mathrm{~mm} /$ year in the west Java trench and $49 \mathrm{~mm} /$ year in the east Java trench [9]. The Benioff seismic zone along the Java segment dips approximately $50^{\circ}$ and extends to depths of about $600 \mathrm{~km}$ and the gap in seismicity exists in the segment between a depth of 300 and $500 \mathrm{~km}$ [9].

Java transform zones occurred on well identified shallow crustal faults in Java Island such as Cimandiri, Lembang, Lasem, Pati and Yogya faults. According to $[6,10]$ no faults of regional extent similar to the Sumatra faults are present in Java Island. For Semarang the closest distance fault, Lasem fault, is considered as the main shallow crustal source that can significantly influence the hazard of the city. Investigation of Lasem fault is therefore very important for microzonation study.

Comprehensive data collection was performed to identify every potential source capable of generating significant ground motion to Semarang. The earthquake data recorded by national agency (Indonesian Agency for Meteorology Climatology and Geophysics/BMKG), international agencies (National Earthquake Information Center and U.S. Geological Survey/NEIC-USGS,
International Seismological Summaries/ISS) and personal catalog [11] were collected for determining seismic hazard parameters for PSHA. Based on the collected earthquake data from 1900 to 2013 with minimum $5 \mathrm{Mw}$ and maximum magnitude (Mmax) 8.3 Mw, all earthquake data are then clustered within radius $500 \mathrm{Km}$ from the study area. All epicenter data are then distributed into subduction, shallow crustal fault, and background sources. Background seismicity used to model random earthquakes on unmapped faults and smaller earthquakes on mapped faults [12]. The background seismicity was divided into four different depth intervals (shallow background $0-50 \mathrm{~km}$, deep background $50-100 \mathrm{~km}$, deep background $100-150$ $\mathrm{km}$ and deep background $150-300 \mathrm{~km}$ ).

The $a-b$ values from Gutenberg Richter (GR) are required as input parameters for PSHA. The parameters are important because they can significantly affect hazard value from PSHA. Based on independent earthquake events, the Guttenberg-Richter parameter (a$\mathrm{b}$ parameter) was calculated and conducted for subduction and background sources.

Faults that have been well identified and influencing Semarang in a radius of $500 \mathrm{~km}$ are Cimandiri, Lembang, Lasem, Pati and Yogya. Parameters of fault required for input of PSHA include fault traces, focal mechanism, slip-rate, dip, length of fault, and maximum magnitude. Location of each fault was determined based on the previous study conducted by TRSHMI-2010 and [2]. Table 1 shows required seismic parameters for PSHA for fault, subduction, and background sources.

\subsection{Seismic hazard analysis}

PSHA was conducted to obtain probabilistic peak ground acceleration (PGA) and spectral acceleration for short periods (0.2 seconds) and long periods (1.0 seconds) at bedrock elevation. Spectral response accelerations at bedrock were calculated for $2 \%$ probability of exceedance in 50 years (2500 years return period of earthquake). This method of analysis was conducted based on the total probability theorem proposed by [13].

Table 1. Seismic sources parameters in a radius of $500 \mathrm{~km}$ from Semarang.

\begin{tabular}{|c|c|c|c|c|c|c|c|}
\hline \multirow{2}{*}{$\begin{array}{l}\text { Seismic } \\
\text { Sources }\end{array}$} & \multirow{2}{*}{ Name } & \multirow{2}{*}{ Mechanism } & \multirow{2}{*}{$\begin{array}{c}\text { Mmax } \\
(\mathrm{Mw})\end{array}$} & \multirow{2}{*}{$\begin{array}{c}\text { Length } \\
(\mathbf{k m})\end{array}$} & \multirow{2}{*}{$\begin{array}{l}\text { Slip Rate } \\
\text { (mm/year) }\end{array}$} & \multicolumn{2}{|c|}{ GR Parameter } \\
\hline & & & & & & $\mathbf{a}$ & b \\
\hline \multirow[t]{5}{*}{ Fault } & Cimandiri & Strike-Slip & 7.2 & 62.2 & 4 & - & - \\
\hline & Lembang & Strike-Slip & 6.6 & 34.4 & 1.5 & - & - \\
\hline & Yogya & Strike-Slip & 6.8 & 31.6 & 2.4 & - & - \\
\hline & Lasem & Strike-Slip & 6.5 & 114.9 & 0.5 & - & - \\
\hline & Pati & Strike-Slip & 6.8 & 51.4 & 0.5 & - & - \\
\hline Subduction & Java Megathrust & Reverse & 8.3 & - & - & 5.36 & 1.0307 \\
\hline \multirow[t]{4}{*}{ Background } & Shallow Background $(0-50 \mathrm{~km})$ & - & 6.8 & - & - & 7.04 & 1.3549 \\
\hline & Deep Background (50-100 km) & - & 8.3 & - & - & 7.62 & 1.4116 \\
\hline & Deep Background (100-150 km) & - & 6.6 & - & - & 5.73 & 1.0608 \\
\hline & Deep Background (150-300 km) & - & 7.5 & - & - & 7.27 & 1.3974 \\
\hline
\end{tabular}


This method of analysis was conducted using threedimensional seismic source model. Geological and seismological data used by TRSHMI-2010 were also conducted for PSHA. According to [13], the probability that a particular level of strong ground motion will be exceeded $\left(\lambda \mathrm{a}^{*}\right)$ is calculated using equation (1) where the value "V", "m" and " $r$ " represents the mean rates of exceedance, seismic magnitude and seismic distance respectively.

$$
\lambda \mathrm{a}^{*}=\mathrm{V} \iint \mathrm{P}(\mathrm{a}>\mathrm{a} * \mid \mathrm{m}, \mathrm{r}) \mathrm{P}_{\mathrm{m}}(\mathrm{m}) \mathrm{P}_{\mathrm{r}}(\mathrm{r}) \mathrm{drdm}
$$

Other important step in seismic hazard analysis is selection of attenuation relationships. Due to inadequate ground motion records to develop attenuation function in Indonesia, attenuation functions used in this study were adopted from other countries and following the work proposed by TRSHMI-2010. The attenuation functions were selected considering the source types. For shallow crustal faults and shallow background sources three attenuation functions used in this study were proposed by $[14,15$ and 16]. Three attenuation functions proposed by [17, 18 and 19] were used for subduction sources. And finally attenuation functions proposed by $[17,18]$ were used for deep background sources.

Following the work proposed by [2] and TRSHMI2010, two PSHA models were implemented using different Vs30 values. The first model (Model-1) was implemented using Vs30 $=760 \mathrm{~m} / \mathrm{s}$ hence the second model (Model-2) was implemented using real Vs30 values. PSHA for both models were conducted at 265 locations which represents 265 boring locations. Fig.1. shows the location of boring investigations. The real Vs30 values for all boring locations were calculated using estimated shear wave velocity (Vs) values at 30 meter top soil deposit by using equation (2). The shear wave velocity values for every soil layer $\left(\mathrm{Vs}_{\mathrm{i}}\right)$ were estimated using three empirical correlation equations proposed by $[3,4,5]$. The value " $d_{i}$ " on equation (1) represents the thickness of each soil layer.

$$
\mathrm{Vs} 30=30 /\left[\Sigma\left(\mathrm{d}_{\mathrm{i}} / \mathrm{Vs}_{\mathrm{i}}\right)\right]
$$

\section{Results and discussions}

Based on the Vs30 values calculated at 265 boring locations the distribution of Vs30 can be seen on Fig. 2 . The distribution of Vs30 as shown in this figure shows that lower Vs30 values are observed along the seaside zone of the town in between $100 \mathrm{~m} / \mathrm{s}$ until $200 \mathrm{~m} / \mathrm{s}$, hence higher Vs30 values observed along the middle and southern part of the study area between $200 \mathrm{~m} / \mathrm{s}$ until $450 \mathrm{~m} / \mathrm{s}$. Fig. 3 shows contour of site class for the whole area of the city. The site class SE, SD and SC were predicted using Vs30 values and following the same method proposed by [1]. Based on the distribution of site class as shown in Fig. 3, site class SE is observed along the northern part of the study area, hence the SD and SC site class are observed along the middle and southern part of the city.
According to [1] site coefficients are divided into FPGA, Fa and Fv which are represents site coefficients for PGA, spectral 0.2 seconds and spectral 1 seconds respectively. FPGA, $\mathrm{Fa}$ and $\mathrm{Fv}$ are predicted by comparing the PGA, short periods (0.2 seconds) and long periods (1.0 seconds) ground acceleration values calculated using Model-2 and Model-1. Fig. 4 shows the distribution of site coefficients FPGA for the study area. Fig. 5 shows the distribution of site coefficients $\mathrm{Fa}$ for the study area.

The distributions of FPGA and $\mathrm{Fa}$ for the whole study area are quite similar. The highest values of both site coefficients are observed in the northern part of the study area, hence the lowest values are observed in the middle and southern part of the study area. The FPGA values are distributed between 1.11 until 1.41 and the Fa values are distributed between 1.14 until 1.30.

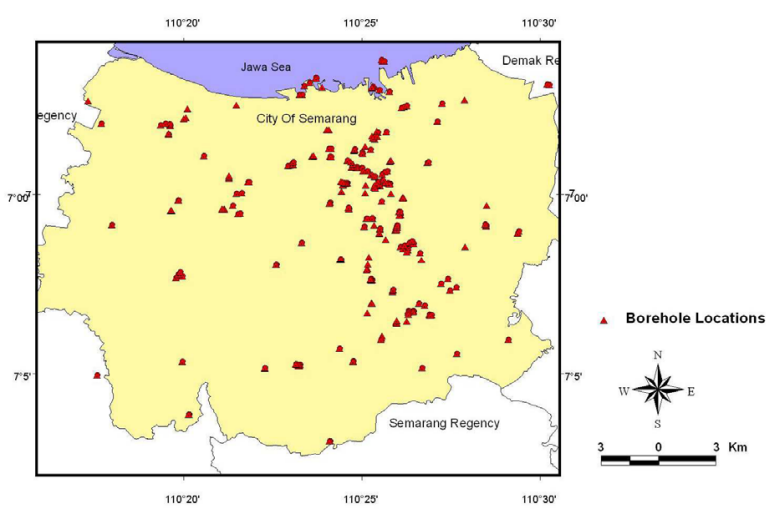

Fig. 1. Location of boring investigations in Semarang
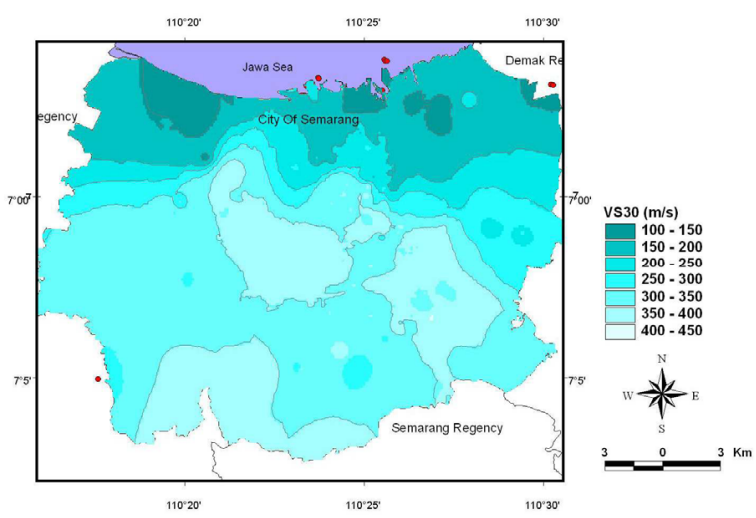

Fig. 2. Contour map of Vs30 in Semarang.

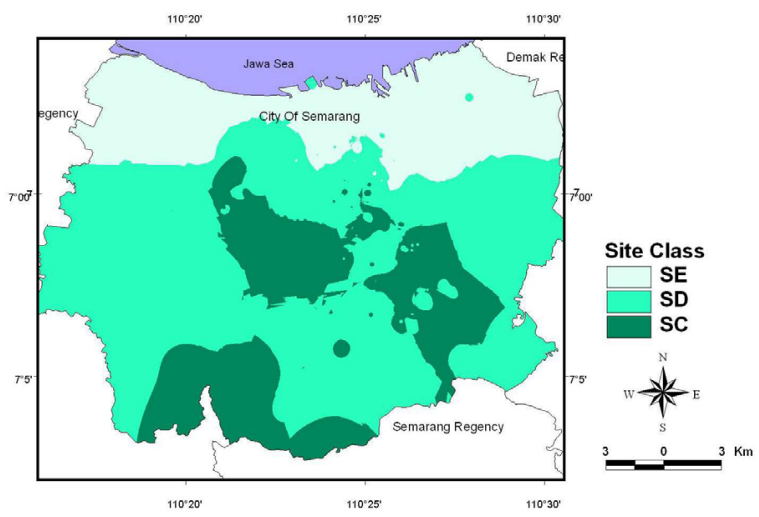

Fig. 3. Contour map of site class in Semarang 


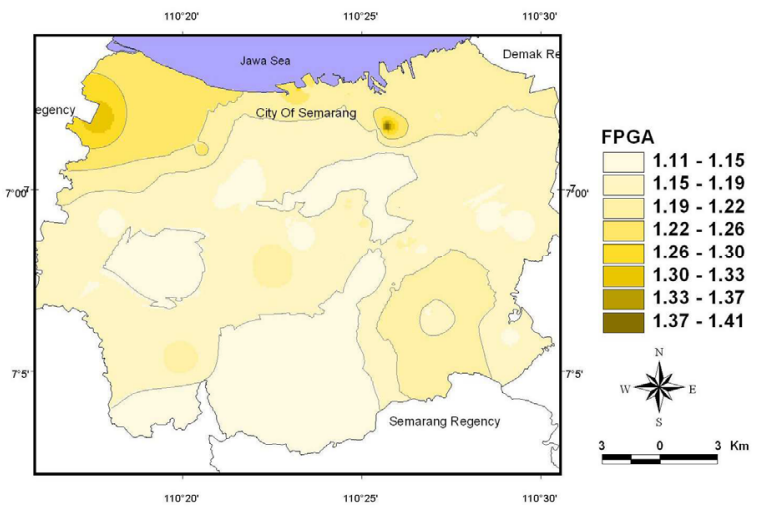

Fig. 4. Contour map of FPGA in Semarang

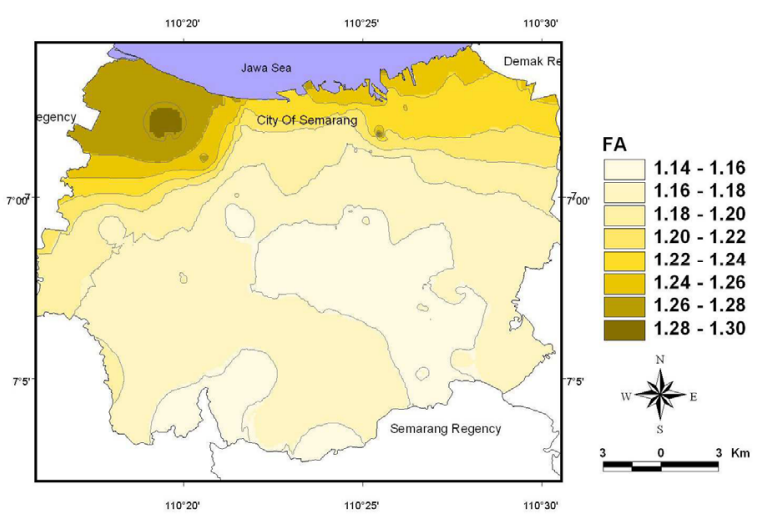

Fig. 5. Contour map of $\mathrm{Fa}$ in Semarang

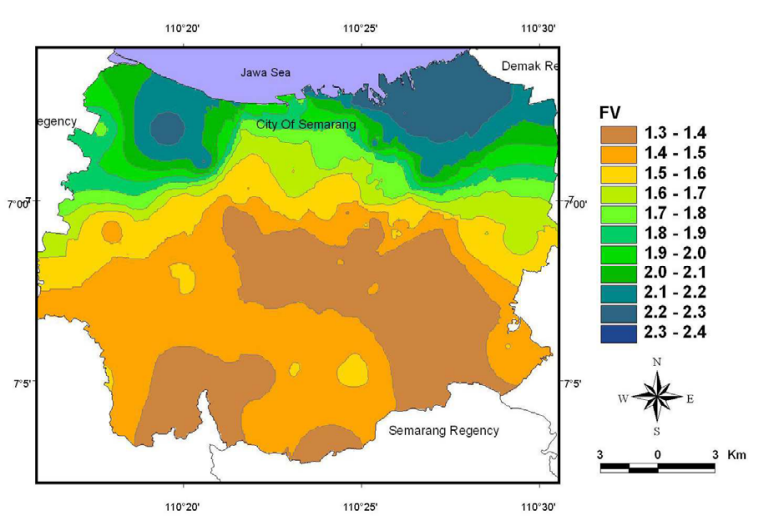

Fig. 6. Contour map of Fv in Semarang

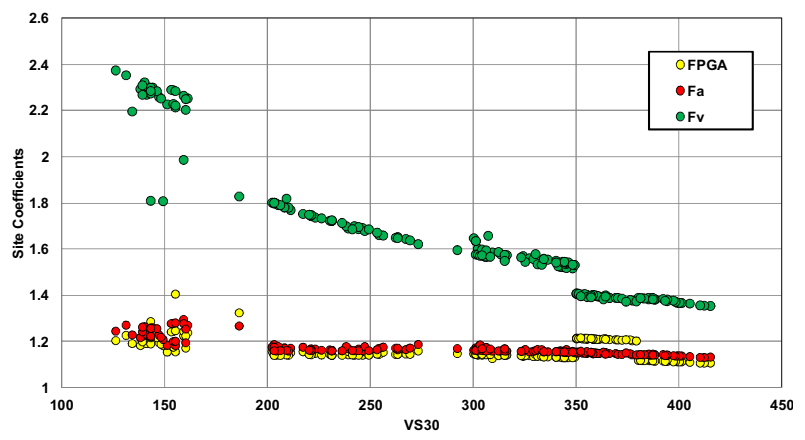

Fig. 7. Graphical plots of Fa, Fv and FPGA in terms of Vs30 in Semarang.

Fig. 6 shows the distribution of Fv for the study area. As can be seen in this figure the highest Fv values is observed along the northern side of the city and distributed between 1.6 until 2.4, however the lowest Fv values is observed in the middle and southern part of the study area, between 1.3 until 1.6.

Fig. 7 shows the FPGA, Fa and Fv plots in terms of Vs30 calculated from 265 locations. Based on site coefficient analysis results calculated from 265 boring investigations it seems that there is a good correlation between increasing of FPGA, Fa and Fv values with decreasing Vs30 values.

Table 2 shows the minimum and maximum spectral accelerations and site coefficients calculated at 265 locations. As shown in this table the PGA values are observed between $0.24 \mathrm{~g}$ until $0.28 \mathrm{~g}$, the spectral $0.2 \mathrm{~s}$ values are observed between $0.50 \mathrm{~g}$ until $0.59 \mathrm{~g}$ and the spectral $1 \mathrm{~s}$ values are observed between $0.16 \mathrm{~g}$ until $0.18 \mathrm{~g}$ where " $\mathrm{g}$ " is gravitational accelerations. The corresponding site coefficients FPGA are observed between 1.11 until 1.41, site coefficients $\mathrm{Fa}$ are observed between 1.14 until 1.30 and site coefficients $\mathrm{Fv}$ are observed between 1.36 until 2.38 .

Table 2. Spectral accelerations and site coefficients calculated at 265 locations

\begin{tabular}{|c|c|c|c|c|c|c|c|}
\hline \multirow{2}{*}{} & \multicolumn{2}{|c|}{ PGA } & \multicolumn{2}{c|}{$\begin{array}{c}\text { Spectra } \\
\text { 0.2s }\end{array}$} & \multicolumn{2}{c|}{$\begin{array}{c}\text { Spectra } \\
\text { 1s }\end{array}$} \\
\cline { 2 - 8 } & $\min$ & $\mathbf{m a x}$ & $\mathbf{m i n}$ & $\mathbf{m a x}$ & $\mathbf{m i n}$ & $\mathbf{m a x}$ \\
\hline \multirow{3}{*}{ SE } & accel.(g) & 0.24 & 0.27 & 0.50 & 0.56 & 0.16 & 0.17 \\
\cline { 2 - 8 } & site cof. & 1.16 & 1.41 & 1.19 & 1.30 & 1.99 & 2.38 \\
\hline \multirow{3}{*}{ SD } & accel.(g) & 0.24 & 0.28 & 0.52 & 0.58 & 0.16 & 0.18 \\
\cline { 2 - 8 } & site cof. & 1.13 & 1.33 & 1.15 & 1.27 & 1.40 & 2.33 \\
\hline \multirow{3}{*}{ SC } & accel.(g) & 0.26 & 0.28 & 0.55 & 0.59 & 0.16 & 0.18 \\
\cline { 2 - 8 } & site cof. & 1.11 & 1.22 & 1.14 & 1.17 & 1.36 & 1.58 \\
\hline
\end{tabular}

Table 3. Average spectral accelerations and site coefficients calculated at 265 locations.

\begin{tabular}{|c|c|c|c|}
\hline \multirow{3}{*}{$\begin{array}{c}\text { Site } \\
\text { Class }\end{array}$} & \multirow{2}{*}{ References } & \multicolumn{2}{|c|}{ Site Coefficients } \\
\cline { 2 - 4 } & & Fa (0.2s) & Fv (1 s) \\
\hline \multirow{4}{*}{ SC } & {$[1]$} & 1.012 & 1.472 \\
\cline { 2 - 4 } & {$[2]$} & 1.14 & 1.53 \\
\cline { 2 - 4 } & {$[20]$} & 1.12 & 1.63 \\
\cline { 2 - 4 } & This study & 1.15 & 1.422 \\
\hline \multirow{4}{*}{ SD } & {$[1]$} & 1.112 & 1.744 \\
\cline { 2 - 4 } & {$[2]$} & 1.35 & 2.29 \\
\cline { 2 - 4 } & {$[20]$} & 1.35 & 2.12 \\
\cline { 2 - 4 } & This study & 1.173 & 1.669 \\
\hline \multirow{4}{*}{ SE } & {$[1]$} & 0.936 & 2.687 \\
\cline { 2 - 4 } & {$[2]$} & 1.55 & 3.56 \\
\cline { 2 - 4 } & {$[20]$} & 1.58 & 3.29 \\
\cline { 2 - 4 } & This study & 1.248 & 2.262 \\
\hline
\end{tabular}

Table 3 shows average $\mathrm{Fa}$ and $\mathrm{Fv}$ values derived from 265 locations at the study area and compared it with the same site coefficients proposed by [1, 2 and 20]. The average values of $\mathrm{Fa}$ and $\mathrm{Fv}$ observed in this study area are quite similar with the same site coefficients proposed by [1, 2 and 20]. 


\section{Conclusions}

Site class and site coefficients maps of Semarang were implemented based on the Vs30 values predicted at 265 locations. The site coefficients were implemented using PSHA by conducting two PSHA models. The Vs30 values used in this study were predicted using N-SPT data. Maximum Vs30 values were observed in the middle and southern part of Semarang while the lowest Vs30 values were identified at the northern part of the study area. The distribution of Vs30 values has a good correlation with the distribution of site class. By using Vs30 distributions for the entire study area, site class SD and SC are identified along the middle and southern part of the city, hence site class SE is identified along the northern part of the study area.

Distribution of site coefficients has a good correlation with the distribution of site class. The lowest FPGA, Fa and Fv site coefficients are identified in the middle and southern part of the study area, hence the highest FGPA, Fa and Fv are identified in the northern part of the study area. Based on two difference models of PSHA it can be seen that the value of FPGA, Fa and Fv can easily be predicted by comparing peak ground acceleration and spectral acceleration calculated using PSHA by conducting real Vs30 of site and Vs30 $=760$ $\mathrm{m} / \mathrm{s}$.

The authors express their sincere gratitude to the National Disaster Management Agency (BNPB) for financial support for this research, Team for Revision of Seismic Hazard Maps of Indonesia 2010 for providing seismic data and technical assistances and USGS for supporting free PSHA software PSHA.

\section{References}

1. Standar Nasional Indonesia, Tata Cara Perencanaan Struktur Bangunan Gedung dan Non Gedung (SNI-03-1726-2012) (2012)

2. M. Asrurifak, Peta Respon Spektra Indonesia untuk Perencanaan Struktur Bangunan Tahan Gempa dengan Model Sumber Gempa Tiga Dimensi dalam Analisis Probabilitas, Disertasi Doktor Teknik Sipil, Institut Teknologi Bandung (2010)

3. Y. Osaki and R. Iwasaki, JSSMFE, Vol. 13, N.4, pp. 59-73, Dec. (1973)

4. Y. Ohta and N. Goto, Earth. Eng. Struc. Dyn., Vol. 6, pp.167-187 (1978)

5. T. Imai and K. Tonouchi, Proceeding of Second
European Symposium on Penetration Testing, Amsterdam, The Netherlands, pp. 67-72 (1982)

6. K.R. Newcomb and W.R. McCann, J. Geophys. Res., Vol. 92, pp. 421-439 (1987)

7. Salahuddin, Jurnal Fakultas Geologi UGM, Yogyakarta (2007)

8. A. Elnashai, S. J. Kim, G.J. Yun, D. Sidharta, The Yogyakarta Earthquake of May 27, 2006, (MidAmerica Earthquake (MAE) Center Report, No 0702, 2007)

9. M. Irsyam, D.T. Dangkua, Hendriyawan, D. Hoedajanto D.B.M. Hutapea, E.K. Kertapati, T. Boen and M.D. Petersen, J. Earth Syst. Sci., Vol. 117, S2, pp. 865-878 (2008)

10. Hamilton, Tectonics of Indonesian Region, (U.S. Government Printing Office, Washington D.C., U.S. Geological Survey Professional Paper, 1078, 345, 1979)

11. E.R. Engdahl, A. Villasenor, H.R. DeShon and C.H. Thurber, Bull. Seismol. Soc. Am., Vol 97, S43-S61 (2007)

12. M. Petersen, S. Harmsen, C. Mueler, K. Haller, J. Dewey, N. Luco, A. Crone, D. Lidke and K. Rukstales, Documentation for the Southeast Asia Seismic Hazard Maps, (Administrative Report September 30, 2007)

13. R.K. McGuire, Bull. Seismol. Soc. Am., Vol. 85, No. 5, pp 1275-1284 (1995)

14. D.M. Boore and G.M. Atkinson, Earthq. Spec., Vol. 24, No. 1, pp. 99-138, Earthq. Eng. Res. Inst. (2008)

15. K.W. Campbell and Y. Bozorgnia, Earthq. Spec., Vol. 24, No. 1, pp. 139-171, Earthq. Eng. Res. Inst. (2008)

16. B.S.J. Chiou and R.R. Youngs, NGA Model for Average Horizontal Component of Peak Ground Motion and Response Spectra, (PEER 2008/09, Pacific Engineering Research Centre, College of Engineering, University of California, Berkeley, 2008)

17. R.R. Youngs, S.J. Chiou, W.J. Silva and J.R. Humprey, Seismol. Res. Lett., 68, pp. 58-73 (1997)

18. G.M. Atkinson and D.M. Boore, Bull. Seismol. Soc. Am., Vol. 93, No. 4, pp. 1703-1729 (2003)

19. X. Zhao, J. Zhang, A. Asano, Y. Ohno, T. Oouchi, T. Takahashi, H. Ogawa, K. Irikura, H. Thio and P. Somerville, Bull. Seismol. Soc. Am., 96, 898 (2006).

20. International Codes Council Inc., International Building Code (IBC) (2009) 